\title{
AUTUMN AND WINTER APPLICATION OF NITROGEN FERTILIZERS ON CLAY SOILS
}

\author{
Yrjö Pessi, Mikko Ylänen, Auvo Leskelä and Jorma Syvälahti
}

\author{
Rikkihappo Oy, Helsinki
}

Received July 7, 1970

\begin{abstract}
In order to examine the application time of nitrogen given to cereals, several tests have been arranged on the Kotkaniemi Experimental Farm at Vihti ever since 1965. The tests have been carried out on solid clay soils, where the leaching of nitrogen has been expected to be slow.

In spring cereals the autumn application of nitrogen in November on frozen soil has given a good crop yield. The protein content of the crop in the plots where nitrogen was given in autumn was lower than in those where the spreading took place in spring.

As for winter wheat, application in December has given the best average crop yields but the decline of the protein content is to be considered a disadvantage. In rye, spring fertilization has given the best average crop yield. There has, however, clearly been less lodging in autumn applications than in plots where the nitrogen was spread in the spring.

Regarding nitrogen fertilization of autumn sown plants the usual custom in Finland is to give nitrogen in autumn for growth during the autumn and in the spring for the coming growing season. However, as low rainfall is typical of the Finnish spring, the effect of nitrogen given by broadcasting in early summer is slow, especially on solid soils like clay. As for spring cereals, the fertilizer placement at a depth of 8 to $10 \mathrm{cms}$ has given distinctly better results than broadcasting and the usual mixing into the soil (Elonen 1967, Larpes 1966 and 1968, Nieminen 1967, Pessi 1970). The difference in the growth intensity has most clearly been evident in the early development of cereals. Simultaneously it has become clear that the placement of nitrogen has been of the greatest importance (Pessi 1970). As during winter in Finland the soil is usually frozen and covered with snow, no noteworthy leaching of nutrients takes place. On the basis of the results and observations mentioned above the question are as to what it would mean in practice in solid soils if the nitrogen was spread already before snowfall or on the snow, when the water from the melting snow would in spring cause the nitrogen to penetrate the soil. For this purpose tests were started on the Kotkaniemi Experimental Farm of Rikkihappo Oy in autumn 1965.
\end{abstract}

\section{Arrangement of test}

The tests were carried out on silty sandy clay through which water penetrates slowly. The physical character of the soil appears in the following analysis: clay, diameter less than $0,002 \mathrm{~mm}, 42 \%$; diameter $0.002-0,2 \mathrm{~mm}, 33 \%$; diameter over $0.02 \mathrm{~mm}, 25 \%$.

In the arrangement of the tests a test plot of such dimensions was planned, even several ares, that the work could be done by farming machines in all its phases while the test plots simultaneously gave a clear picture of the growth form of the crops. There were usually 4 replications. In large test plots the unhomogeneity of the soil causes more dis- 
persion than in small ones; also the area needed by the test plot is large, positive points on the fact that it is possible to use ordinary farm-working techniques and to adapt the results directly into practice.

The meteorological conditions are shown in Table 1.

Table 1. Meteorological Observations at Vihti during the Growing Seasons 1965-69.

Monthly precipitations in millimetres

$\begin{array}{lrrrrrr} & \text { V } & \text { VI } & \text { VII } & \text { VIII } & \text { IX } & \text { Total } \\ 1965 & 8.3 & 18.1 & 106.9 & 90.0 & 65.0 & 288.3 \\ 1966 & 15.1 & 40.7 & 74.9 & 28.3 & 77.7 & 236.7 \\ 1967 & 51.9 & 21.8 & 27.8 & 142.1 & 53.3 & 296.9 \\ 1968 & 70.5 & 30.6 & 67.1 & 111.4 & 74.4 & 354.0 \\ 1969 & 21.6 & 15.5 & 45.3 & 40.1 & 95.9 & 218.4 \\ \text { Average } & 33.5 & 25.3 & 64.4 & 82.4 & 73.3 & 278.8\end{array}$

Average temperatures per monthly in ${ }^{\circ} \mathrm{C}$

\begin{tabular}{lrrrrrr} 
& V & VI & VII & VIII & IX & $\begin{array}{l}\text { Average } \\
(\text { V-IX) }\end{array}$ \\
1965 & 7.7 & 16.0 & 14.6 & 13.4 & 11.6 & 12.66 \\
1966 & 9.4 & 17.9 & 17.9 & 13.8 & 7.9 & 13.38 \\
1967 & 10.1 & 14.7 & 17.6 & 15.2 & 10.5 & 13.62 \\
1968 & 7.4 & 16.2 & 14.5 & 15.3 & 10.0 & 12.68 \\
1969 & 8.7 & 15.3 & 16.2 & 15.2 & 9.6 & 13.00 \\
\hline Average & 8.7 & 16.0 & 16.2 & 14.6 & 9.9 &
\end{tabular}

\section{Results}

S p ring cereals. The tests were started by using spring cereal as an experimental plant in fertilizations in autumn 1965. In 1966 they were expanded to include also winter cereals.

The results of the experiments with compound fertilizer (8-13-9, N- $\mathrm{P}_{2} \mathrm{O}_{5}-\mathrm{K}_{2} \mathrm{O}$ ) are given in Table 2. Nitrogen given in autumn has in the tests given a clear increase in the crop yield, but spring fertilization has proved even better. However, it is to be noted that the superiority of spring fertilization in this case cannot with certainty be attributed to the better effect of nitrogen. It is well known that water-soluble phosphorus, which the used compound fertilizer contains, fixes fairly fast in a less soluble form. In autumn application this has happened more than in the spring application.

The three quality factors of the crop yield in Table 2 have not been affected by the time of fertilization. There has been no noteworthy lodging in any treatment.

Tables 3 and 4 present the 4-year results of the tests carried out with four different nitrogen fertilizers. They show that different fertilizers have given very similar results. Autumn application in November has usually given the best results, ammonium sulphate alone has proved an exception, in a way against all expectations. In the quality of the crop yield a clear consistency is to be seen in the protein contents of the cereals. In connection with autumn applications it is lower than in spring applications. 


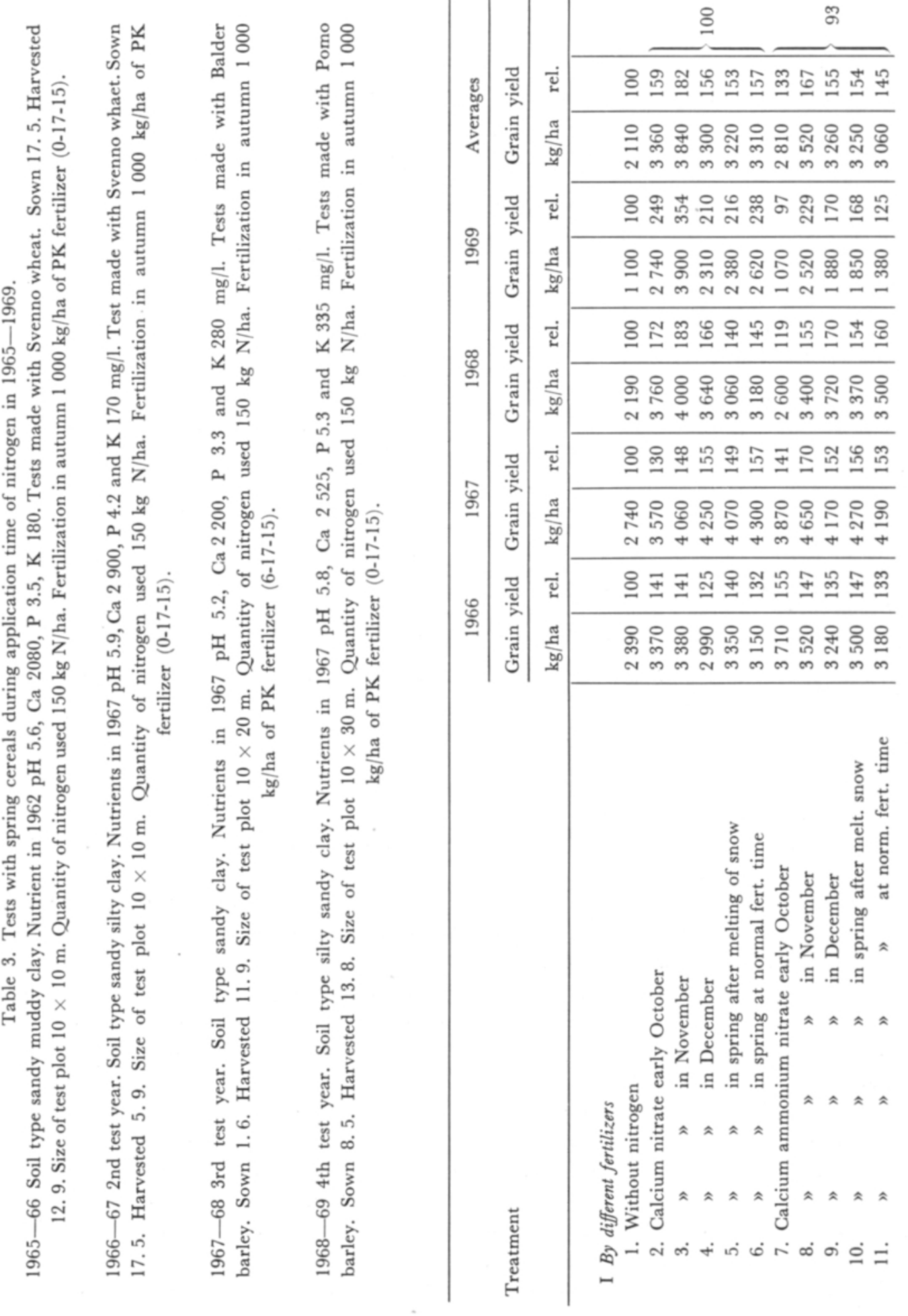




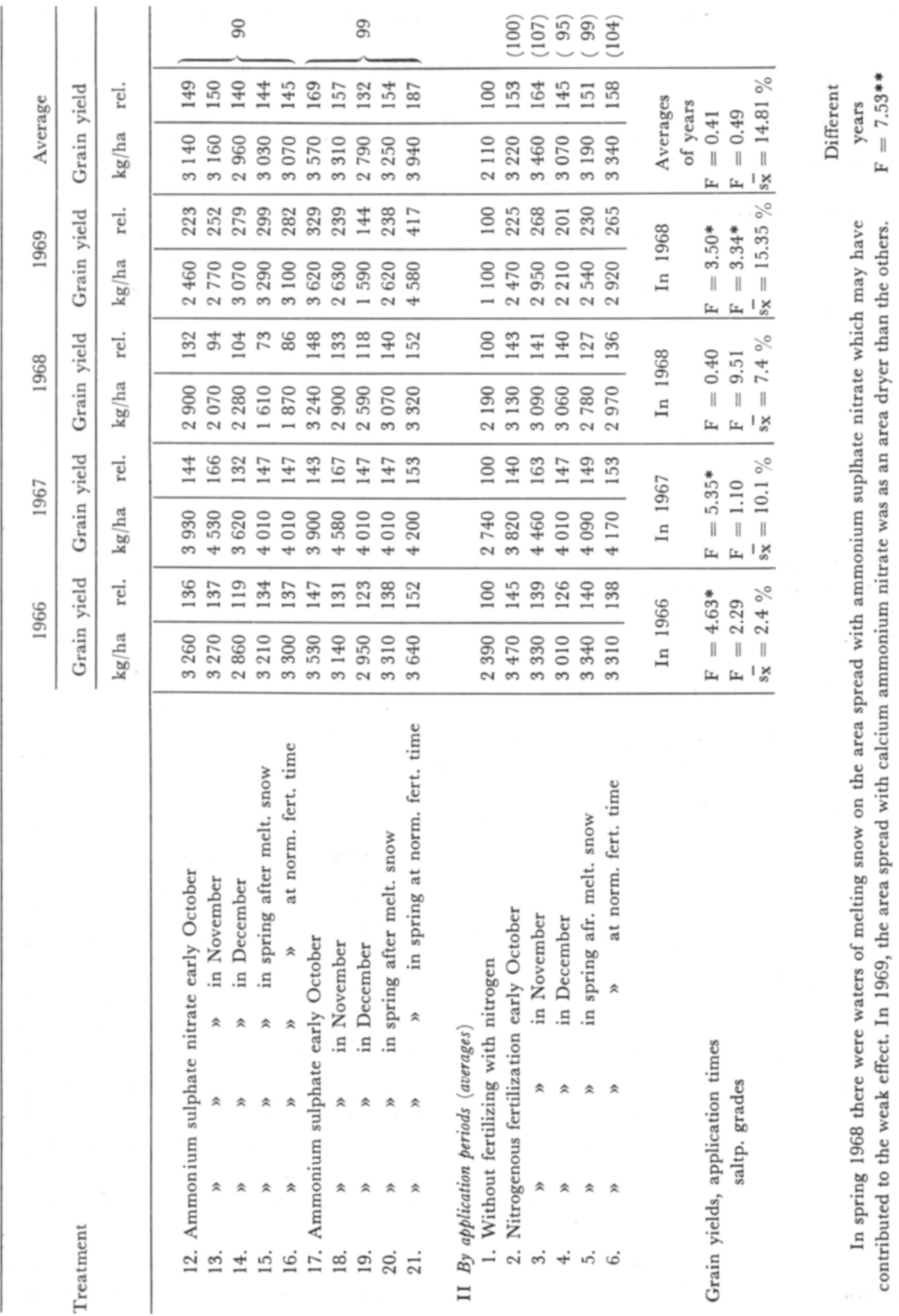


Table 2. Average values of results from tests with spring cereals during application time of fertilizers (compound fertilizer 8-13-9) in 1965-69.

1965-66 Soil type sandy muddy clay. Nutrients in 1962 pH 5, 6, Ca 2080, P 3.5, K 180. Test made with Svenno spring wheat. Size of test plot $10 \mathrm{~m} \times 50 \mathrm{~m} .3$ replications. Fertilization: $800 \mathrm{~kg} / \mathrm{ha}$ of compound fertilizer 8-13-9.

1966-67 Soil type silty clay. Nutrients in 1967 pH 5,9, Ca 2900 , P 4.2 and K 170 mg/l. Test made with Svenno wheat. Size of test plot $10 \mathrm{~m} \times 50 \mathrm{~m}$. 3 replications. Fertilization: $800 \mathrm{~kg} / \mathrm{ha}$ of compound fertilizer 8-13-9.

1967-68 Soil type clayey humus soil. Nutrients in 1967 pH 5.2, Ca 2475 , P 4.4 and K 300 mg/l. Test made with Balder barley. Size of test plot $10 \mathrm{~m} \times 50 \mathrm{~m}$. 4 replications Fertilization: $800 \mathrm{~kg} / \mathrm{ha}$ of $\mathrm{com}-$ pound fertilizer 8-13-9.

1968-69 Soil type silty sandy clay. Nutrients in 1967 pH 5.8, Ca 2390 , P 5.7 and K 364 mg/l. Test made with Pomo barley. Sown 8.5. Harvested 12. 8. Size of test plot $10 \mathrm{~m} \times 50 \mathrm{~m}$. 4 replications. Fertilization: $800 \mathrm{~kg} / \mathrm{ha}$ of compound fertilizer 8-13-9.

Treatment

\section{Grain yield}

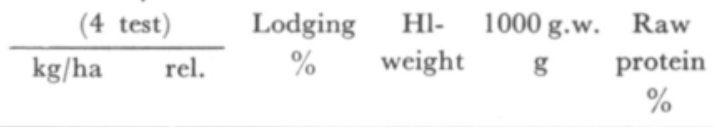

1. Without fertilization (test results only from

1966-67) 1820

2. $\mathrm{PK}$ fertilization on ploughed area early October 1890

3. 8-13-9 fertilization before ploughing " " 2500

4. " " after ploughing " " 2560 5. " " on ploughed area after mid-

dle of November

6. 8-13-9 fertilization on ploughed in spring after melting of snow

2650

$\begin{array}{llll}100 & 0 & 81.7 & 35.0\end{array}$

$\begin{array}{llll}104 & 1 & 75.2 & 37.6\end{array}$

$\begin{array}{lllll}137 & 1 & 76.1 & 37.9 & 10.0\end{array}$

8-13-9 fertilization on ploughed in spring at normal fertilizing time

$\begin{array}{lrrrrr}3080 & 169 & 9 & 74.9 & 40.1 & 10.2 \\ 2880 & 158 & 0 & 75.0 & 38.7 & 10.0\end{array}$

Grain yields In 1966 In 1967

In 1968 In 1969

$$
\begin{array}{llll}
\mathrm{F}=16.35 * * * & \mathrm{~F}=7.54 * * & \mathrm{~F}=4.54 * & \mathrm{~F}=2.66 \\
\overline{\mathrm{s}_{\mathbf{x}}}=3.11 \% & \overline{\mathrm{s}_{\mathbf{x}}}=9.06 \% & \mathrm{~s}_{\overline{\mathrm{x}}}=6.70 \% & \mathrm{~s}_{\mathbf{x}}=12.54 \%
\end{array}
$$

$\mathrm{W}$ i n t e r c e re a $1 \mathrm{~s}$. The results of the tests carried out with winter cereals are presented in Tables 5 to 8 . Tables 5 and 6 show the results of winter rye and Tables 7 and 8 those of winter wheat. No treatment without nitrogen fertilization was included in the tests but on the basis of other tests made in the same area it is possible to conclude that the crop yield without nitrogen fertilization is for rye $2140 \mathrm{~kg} /$ hectare and for winter wheat $2270 \mathrm{~kg} /$ hectare. The results show that for rye spring fertilization has given the best results on an average, and for winter wheat spreading in December. Yearly fluctuations have apparently existed, at least partly, because of the rain frequency of the spring. There have been clear differences in lodging. The smaller lodging of rye in connection with autumn applications compared with spring applications would seem to recommend autumn application of nitrogen on clay soils in connection with intensive cultivation aiming at high crop yield. On the other hand, the decline of the protein content of winter wheat in connection with autumn application of nitrogen is a disadvantage for the baking quality of the crop. 


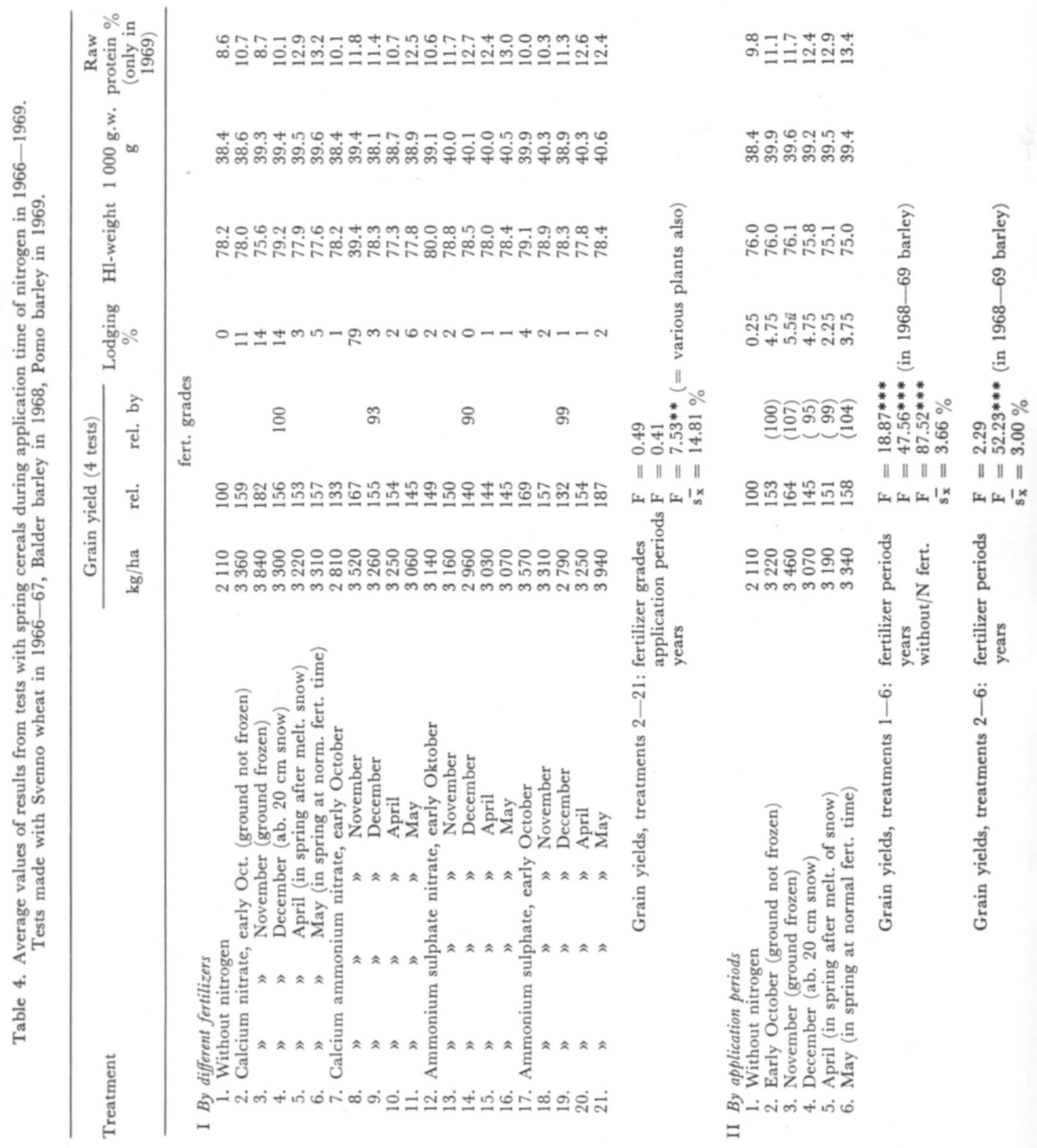


Table 5. Test with winter rye during nitrogen application time.

1966-67 Soil type silty sandy clay. Nutrients in 1967 pH 5.8, Ca 2 500, P 5.3 and K 335 mg/l. Fertilization in connection with seed-bed preparation $500 \mathrm{~kg}$ compound fertilizer (8-13-9) and $600 \mathrm{~kg} / \mathrm{ha} \mathrm{PK}$ fertilizer (0-17-15) by broadcasting. Tests made with Pekka rye. Size of test plot $5 \mathrm{~m} \times 50 \mathrm{~m} .4$ replications. For shoots $150 \mathrm{~kg} \mathrm{~N} / \mathrm{ha}$ as calcium ammonium nitrate.

1967-68 Soil type silty clay. Nutrients in 1967 pH 5.8, Ca 2600 , P 6.4 and K $220 \mathrm{mg} / \mathrm{l}$. Fertilization in connection with seed-bed preparation $600 \mathrm{~kg}$ compound fertilizer (8-13-9) and $500 \mathrm{~kg} / \mathrm{ha}$ PK fertilizer by drilling. Tests made with Pekka rye. Size of test plot $10 \mathrm{~m} \times 20 \mathrm{~m}$. 4 replications. For shoots $150 \mathrm{~kg}$ $\mathrm{N} / \mathrm{ha}$ as calcium ammonium nitrate.

1968 - 69 Soil type clayey sand and silt. Nutrients in 1967 pH 5.8, Ca 2 100, P 10 and K 315 mg/l. Fertilization in connection with seed-bed preparation $700 \mathrm{~kg} / \mathrm{ha}$ compound fertilizer (15-25-10) by drilling. Tests made with Pekka rye. Size of test plot $7 \mathrm{~m} \times 27 \mathrm{~m} .3$ replications. For shoots $150 \mathrm{~kg} \mathrm{~N} / \mathrm{ha}$ as calcium ammonium nitrate.

\begin{tabular}{|c|c|c|c|c|c|c|c|c|}
\hline \multirow[t]{2}{*}{ Nitrogen application time } & \multicolumn{2}{|c|}{$\begin{array}{c}1967 \\
\text { Grain yield }\end{array}$} & \multicolumn{2}{|c|}{$\begin{array}{c}1968 \\
\text { Grain yield } \\
\end{array}$} & \multicolumn{2}{|c|}{$\begin{array}{c}1969 \\
\text { Grain yield }\end{array}$} & \multicolumn{2}{|c|}{ Averages } \\
\hline & $\mathrm{kg} / \mathrm{ha}$ & rel. & $\mathrm{kg} / \mathrm{ha}$ & rel. & $\mathrm{kg} / \mathrm{ha}$ & rel. & $\mathrm{kg} / \mathrm{ha}$ & rel. \\
\hline 1. Early October & 3540 & 100 & 1920 & 100 & 3740 & 100 & 3070 & 100 \\
\hline 2. " November & 4040 & 114 & 1870 & 98 & 3410 & 91 & 3110 & 101 \\
\hline 3. " December & 4070 & 115 & 1800 & 93 & 3370 & 90 & 3080 & 100 \\
\hline 4. $20-40 \mathrm{~cm}$ snow & 4070 & 115 & 1860 & 97 & 3180 & 102 & 3250 & 106 \\
\hline 5. In spring after melting of snow & 3960 & 112 & 2340 & 122 & 3740 & 100 & 3350 & 109 \\
\hline 6. At normal spreading time & 3980 & 112 & 2430 & 127 & 3980 & 106 & 3460 & 113 \\
\hline$\underset{s \bar{x}}{\text { Grain yields }}$ & $\begin{aligned} & 196 \\
F & =1 . \\
& =4 .\end{aligned}$ & $\begin{array}{l}7 \\
15 \\
74 \%\end{array}$ & $\begin{array}{r}196 \\
F=3 . \\
6 .\end{array}$ & $\begin{array}{l}8 \\
95 * \\
70 \%\end{array}$ & $\begin{aligned} & 196 \\
F & =1 . \\
= & 6 .\end{aligned}$ & $27 \%$ & & \\
\hline
\end{tabular}

Table 6. Test with winter rye during nitrogen application time.

1966-67 Soil type silty sandy clay. Nutrients in 1967 pH 5.8, Ca 2 500, P 5.3 and K 335 mg/l. Fertilization in autumn 1966 with $500 \mathrm{~kg}$ compound fertilizer (8-13-9) and with $600 \mathrm{~kg} / \mathrm{ha}$ PK fertilizer (017-15) by broadcasting. Tests made with Pekka rye. Size of test plot $5 \mathrm{~m} \times 50 \mathrm{~m} .4$ replications. Fertilizing with $150 \mathrm{~kg} \mathrm{~N} / \mathrm{ha}$ as calcium ammonium nitrate.

1967-68 Soil type silty clay. Nutrients in 1967 pH 5.8, Ca 2600 , P 6.4 and K 220 mg/l. Fertilization in connection with seed-bed preparation: $600 \mathrm{~kg}$ compound fertilizer (8-13-9) and $500 \mathrm{~kg}$ PK fertilizer/ha by drilling. $150 \mathrm{~N} / \mathrm{ha}$ as calcium ammonium nitrate given for shoots. Tests made with Pekka rye. Size of test plot $10 \mathrm{~m} \times 20 \mathrm{~m}$. 4 replications.

1968 - 69 Soil type clayey sand and silt. Nutrients in 1967 pH 5.8, Ca 2 100, P 10 and K 315 mg/l. Fertilization in connection with seed-bed preparation with $700 \mathrm{~kg} / \mathrm{ha}$ compound fertilizer (15-25-10) by drilling. For shoots $150 \mathrm{~N} / \mathrm{ha}$ as calcium ammonium nitrate. Tests made with Pekka rye. Size of test plot $7 \mathrm{~m} \times 27 \mathrm{~m} .3$ replications. 


\begin{tabular}{|c|c|c|c|c|c|c|c|c|}
\hline Treatment & Grain & yield & $\begin{array}{c}\text { Lodging } \\
\%\end{array}$ & $\begin{array}{c}\text { Over- } \\
\text { wintering } \\
\text { observ. } \\
13.4 .67 . \\
\text { covering } \\
\%\end{array}$ & $\begin{array}{c}\mathrm{Hl}- \\
\text { weight }\end{array}$ & $\begin{array}{c}1000 \\
\text { g.w. } \\
\text { g }\end{array}$ & $\begin{array}{l}\text { Falling } \\
\text { number }\end{array}$ & $\begin{array}{c}\text { Raw } \\
\text { protein } \\
\left.\%^{1}\right) \times\end{array}$ \\
\hline 1. Early October & 3070 & 100 & 36.8 & 92.8 & 75.9 & 26.6 & 190 & 9.6 \\
\hline 2. " November & 3110 & 101 & 38.3 & 89.0 & 76.1 & 28.5 & 207 & 9.8 \\
\hline 3. " December & 3080 & 100 & 41.0 & 88.4 & 76.4 & 26.0 & 196 & 11.2 \\
\hline 4. $40 \mathrm{~cm}$ snow & 3250 & 106 & 41.2 & 90.3 & 76.6 & 25.8 & 192 & 10.1 \\
\hline 5. In spring after melting of snow & 3350 & 109 & 77.7 & 89.5 & 75.9 & 26.5 & 191 & 12.4 \\
\hline 6. At normal fertilizing time & 3460 & 113 & 82.8 & 89.4 & 75.7 & 26.3 & 189 & 10.6 \\
\hline
\end{tabular}

Grain yields, $\mathrm{F}$-value $=0.15$ (different years $\mathrm{F}=12.27 * *$ )

1) Only in 1969.

Table 7. Test with winter wheat during nitrogen application time.

1966-67 Soil type silty sandy clay. Nutrients in 1967 pH 5.9, Ca 3100 , P 8.8 and K 170 mg/l. Fertilization in connection with seed-bed preparation with $1000 \mathrm{~kg} / \mathrm{ha} \mathrm{PK}$ fertilizer (0-17-15) by broadcasting. Tests made with Linna wheat. Sown 3. 9. 66. Harvested 23. 8. Size of test plot $5 \mathrm{~m} \times 50 \mathrm{~m}$. 4 replications.

For shoots $150 \mathrm{~kg} \mathrm{~N} / \mathrm{ha}$ as calcium ammonium nitrate.

1967-68 Soil type silty clay. Nutrients in 1967 pH 5.5, Ca 3375 , P 4.0 and K 290 mg/l. Fertilization in connection with seed-bed preparation: $600 \mathrm{~kg}$ compound fertilizer (8-13-9) and $500 \mathrm{~kg}$ PK fertilizer/ha by drilling. Test made with Linna wheat. Sown 7. 9. 67. Harvested 22. 8. 68. Size of test plot $8 \mathrm{~m} \times 30 \mathrm{~m}$. 4 replications. For shoots $150 \mathrm{~kg} \mathrm{~N} / \mathrm{ha}$ as calcium ammonium nitrate.

1968-69 Soil type clayey sand and silt. Nutrients in $1967 \mathrm{pH} \mathrm{5.8,} \mathrm{Ca} 2$ 025, P 4.8 and K $284 \mathrm{mg} / \mathrm{l}$. Fartilization in connection with seed-bed preparation with $700 \mathrm{~kg} / \mathrm{ha}$ compound fertilizer (15-25-10) by drilling. Tests made with Linna wheat. Sown 5.9.68. Harvested 12. 8. 69. Size of test plot $10 \mathrm{~m} \times$ $50 \mathrm{~m} .4$ replications. For shoots $150 \mathrm{~kg} \mathrm{~N} / \mathrm{ha}$ as calcium ammonium nitrate. (When coming into ear another $200 \mathrm{~kg} / \mathrm{ha}$ calcium ammonium nitrate was given).

\begin{tabular}{|c|c|c|c|c|c|c|c|c|}
\hline \multirow[t]{2}{*}{ Nitrogen application time } & \multicolumn{2}{|c|}{$\begin{array}{c}1967 \\
\text { Grain yield }\end{array}$} & \multicolumn{2}{|c|}{$\begin{array}{c}1968 \\
\text { Grain yield }\end{array}$} & \multicolumn{2}{|c|}{$\begin{array}{c}1969 \\
\text { Grain yield }\end{array}$} & \multicolumn{2}{|c|}{$\begin{array}{c}\text { Averages of } \\
\text { all years }\end{array}$} \\
\hline & $\mathrm{kg} / \mathrm{ha}$ & rel. & $\mathrm{kg} / \mathrm{ha}$ & rel. & $\mathrm{kg} / \mathrm{ha}$ & rel. & $\mathrm{kg} / \mathrm{ha}$ & rel. \\
\hline 1. Early October & 4700 & 100 & 1900 & 100 & 1230 & 100 & 2610 & 100 \\
\hline 2. " November & 4890 & 104 & 2340 & 123 & 1070 & 87 & 2770 & 106 \\
\hline 3. " December & 4510 & 96 & 3230 & 170 & 1190 & 97 & 2980 & 114 \\
\hline 4. $20-40 \mathrm{~cm}$ snow & 4550 & 97 & 2860 & 150 & 1300 & 105 & 2900 & 111 \\
\hline 5. In spring after melting of snow & 3920 & 83 & 3380 & 178 & 1190 & 97 & 2830 & 108 \\
\hline 6. At normal application time & 4110 & 87 & 3090 & 163 & 1080 & 88 & 2760 & 106 \\
\hline
\end{tabular}

$\begin{array}{lrcc} & 1967 & 1968 & 1969 \\ \text { Grain yields } & \mathrm{F}=5.32 * * & \mathrm{~F}=3.16 * & \mathrm{~F}=0.43 \\ \overline{\mathrm{s}} & 3.54 \% & 11.50 \% & 11.53 \%\end{array}$


Table 8. Test with winter wheat during nitrogen application time.

1966-67 Soil type silty sandy clay. Nutrients in $1967 \mathrm{pH} \mathrm{5.9,} \mathrm{Ca} 3100$, P 8.8 and K $170 \mathrm{mg} / \mathrm{l}$. Store fertilization with $1000 \mathrm{~kg} / \mathrm{ha}$ PK fertilizer (0-17-15) on the surface. Tests made with Linna wheat. Sown 3. 9. 66. Harvested 23. 8. Size of test plot $5 \mathrm{~m} \times 50 \mathrm{~m}$. 4 replications. As fertilizer $150 \mathrm{~kg} \mathrm{~N} / \mathrm{ha}$ calcium ammonium nitrate.

1967-68 Soil type silty clay. Nutrients in 1967 pH 5.5, Ca 3375 , P 4.0 and K 290 mg/l. Fertilization in connection with seed-bed preparation: $600 \mathrm{~kg}$ compound fertilizer (8-13-9) and $500 \mathrm{~kg}$ PK fertilizer/ha by drilling. Tests made with Linna wheat. Sown 7.9.67. Harvested 22. 8. 68. Size of test plot $8 \mathrm{~m} \times$

$30 \mathrm{~m} .4$ replications. In the fertilization $150 \mathrm{~g} / \mathrm{ha} \mathrm{N}$ as calcium ammonium nitrate has been used.

1968-69 Soil type clayeye sand and silt. Nutrinets in 1967 pH 5.8, Ca 2025 , P 4.8 and K 284 mg/l. Fertilization in connection with seed:bed preparation with $700 \mathrm{~kg} / \mathrm{ha}$ compound fertilizer (15-25-10), by drilling. For shoots $150 \mathrm{~kg} / \mathrm{ha} \mathrm{N}$ as calcium ammonium nitrate. Tests made with Linna wheat. Sown 5. 9. 68. Harvested 12. 8. 69. Size of test plot $10 \mathrm{~m} \times 50 \mathrm{~m} .4$ replications. (When coming into ear another $200 \mathrm{~kg} / \mathrm{ha}$ calcium ammonium nitrate was given).

\begin{tabular}{|c|c|c|c|c|c|c|c|c|}
\hline \multirow[b]{2}{*}{ Treatment } & \multirow{2}{*}{$\begin{array}{l}\text { Grain } \\
\mathrm{kg} / \mathrm{ha}\end{array}$} & \multirow[b]{2}{*}{ rel. } & \multirow[b]{2}{*}{$\begin{array}{c}\text { Lodging } \\
\%\end{array}$} & \multirow{2}{*}{$\begin{array}{c}\text { Over- } \\
\text { winter } \\
\text { observ. } \\
13.4 .67 . \\
\text { covering } \\
\% \\
\end{array}$} & \multirow[b]{2}{*}{$\begin{array}{c}\mathrm{Hl}- \\
\text { weight }\end{array}$} & \multirow{2}{*}{$\begin{array}{c}1000 \\
\text { g.w. } \\
\text { g }\end{array}$} & \multirow[b]{2}{*}{$\begin{array}{l}\text { Falling } \\
\text { number }\end{array}$} & \multirow{2}{*}{$\begin{array}{c}\text { Raw } \\
\text { protein } \\
\%\end{array}$} \\
\hline & & & & & & & & \\
\hline 1. Early October & 2610 & 100 & 17.1 & 95.5 & 76.9 & 33.3 & 262 & 11.7 \\
\hline 2. " November & 2770 & 106 & 17.3 & 95.5 & 78.9 & 33.2 & 253 & 12.2 \\
\hline 3. " December & 2980 & 114 & 21.9 & 96.0 & 78.9 & 35.6 & 256 & 12.6 \\
\hline 4. $40 \mathrm{~cm}$ snow & 2900 & 111 & 15.0 & 96.2 & 79.3 & 34.2 & 249 & 12.2 \\
\hline 5. In spring after melting of snow & 2830 & 109 & 27.5 & 95.5 & 79.0 & 35.1 & 266 & 12.6 \\
\hline 6. At normal fertilizing time & 2760 & 106 & 25.3 & 96.5 & 78.1 & 35.2 & 258 & 13.2 \\
\hline
\end{tabular}

$\mathrm{F}=0.23($ different years $\mathrm{F}=76.67 * * *)$

The protein contents of the grain yield are smaller because of the nitrogen application in autumn than they would be after application in spring. A factor which may be of importance e.g. in the cultivation of malting barley.

Concerning tests carried out elsewhere in Finland, the results over one year have been published in two experimental farms (KöyliJÄrvi 1969, VARIs 1969). In the tests Köylijärvi carried out in Mietoinen in 1969, the spring application of calcium ammonium nitrate gave better results for winter wheat than application in autumn or early winter, but when broadcasting was used the December application of compound fertilizer (1520-15) gave a better result than spring application. In the tests carried out by Varis in Anttila, autumn application has given better results for winter wheat than spring application, but the protein contents have been lower respectively (11.4 and $12.5 \%$ ). A similar decline in protein contents has been noted in tests carried out in the U.S.A. (STEVENSON et al. 1969). PaAvilainen (1970) noted in the fertilization of marshland forest that part of the nitrogen fertilizer spread on snow late in winter was lost. 
In the U.S.A. Aldrich (1969) has examined the spreading time of nitrogen on corn and found autumn application about as good as spring application in northern regions where the temperature of the soil is low in winter. Also tests in Hungary have given similar results for winter wheat in autumn and spring applications, when the autumn application has been given into frozen soil (Dudas et al. 1968). Nöммік (1966) in Sweden has also paid attention to nitrogen keeping over the winter.

In Oregon, U.S.A., Cooper (1956) has found nitrogen given in spring and in autumn equally effective for hay.

\section{REFERENCES}

Aldrich, S. R. 1969. Fall application. Agr. Chem. 24, 6: 12-14.

Cooper, C. S. 1956. The effect of source, rate and time of nitrogen application on the yields, vegetative composition and crude protein content of native floodmeadow hay in eastern Oregon. Agr.J. 48: $543-545$.

Dudàs, F., Jelinek, K. \& Pelikàn, M. 1968. Method of fertilization with nitrogen in relation to yield an d quality to winter wheat. Rostl. Vyroba 14, 5: 489-498.

Elonen, P., Nieminen, L. \& Kara, O. 1967. Tuloksia kevätviljojen sadetuksesta savimailla. Maat. ja Koetoim. 21: 7-17.

KöYLIJÄRVI, J. 1969. Näinkin voi käydä ... Koetoim. ja Käyt. 26: 37.

LARPES, G. 1966. Rivilannoituksen vaikutus kevätviljoissa. Maat. ja Koetoim. 20: 14-20.

-»-1968. Rivilannoituskokeet vv. 1965-67. Maaseudun Tulevaisuus 52. 12. 58-59.

Nieminen, L., Kara, O. \& Elonen, P. 1967. Kokemuksia sijoituslannoituksesta. Maat. ja Koetoim. 21: $42-49$.

Nöммгк, H. 1961. Kalium- und ammoniumfixierung in schwedischen Ackerböden. K. skogs- och lantbr. akad. tidskrf. Suppl. 5: 28-39.

- - The residual effects of nitrogen fertilizers in relation to the quantities of mineral nitrogen recovered in the soil profile. Acta Agric. Scand. 16: 163-178.

PAAvilainen, E. 1970. Tutkimuksia levitysajankohdan vaikutuksesta nopealiukoisten lannoitteiden aiheuttamiin kasvureaktioihin suometsissä. Folia Forest. 75: 1969.

Pessi, Y. 1969. Typpilannoitteiden syyslevityksestä. Leipä leveämmäksi 4: 29-31.

-»- YLÄNen, M., Leskelä, A. \& SyväLAhti, J. 1970. Results of tests made with placement fertilization on the Kotkaniemi experimental farm. J. Sci. Agric. Soc. Finl. 42: 193-202.

Stevensson, C. K. \& Baldwin, D. S. 1969. Effect of time and Method of Nitrogen Application and Source of Nitrogen on the yield and Nitrogen Content of Corn. Agr. J. 61: 381-384.

VARIs, E. Syysvehnän laadusta vehnän tuotannon pulma? Pellervo 70: 1186-1187.

\section{SELOSTUS}

\section{TYPPEÄ SISÄLTÄVIEN LANNOITTEIDEN SYYS- JA TALVILEVITYKSESTÄ SUOMESSA}

Yrjö Pessi, Mikko Ylänen, Auvo Leskelä ja Jorma Syvälahtı

\section{Rikkihappo Oy, Helsinki}

Viljoille annettavan typen levitysajan tutkimiseksi on Kotkaniemen koetilalla Vihdissä järjestetty useita kokeita vuodesta 1965 lähtien. Kokeet on tehty tiiviillä savimailla, joilla typen kulkeutuminen on oletettu hitaaksi.

Kevätviljoilla typen syyslevitys marraskuussa routaantuneelle maalle on antanut hyvän satotuloksen. Sadon valkuaispitoisuus syksyllä typen saaneilla alueilla on alempi kuin keväällä levitetyillä alueilla.

Syysvehnällä on joulukuun levitys antanut keskimäärin parhaan sadon, mutta valkuaispitoisuuden aleneminen on luettava haitaksi. Rukiilla on kevätlannoitus antanut keskimäärin parhaan sadon. Lakoutuminen on kuitenkin syyslevityksessä ollut selvästi vähäisempää kuin keväällä typen saaneilla alueilla. 